Golden Age: Jurnal Pendidikan Anak Usia Dini, Volume 3 Nomor 2 (Desember 2019)

ISSN 2549-8371 | E-ISSN 2580-5843

Fitri Siti Sundari, Yuli Mulyawati, Tustiyana Windiyani, Eva Mutia / Relationship of Fine Motor

Skills with Vertical Writing Skills at Papandayan Public Elementary School Bogor

\title{
Relationship of Fine Motor Skills with Vertical Writing Skills at Papandayan Public Elementary School Bogor
}

\author{
FITRI SITI SUNDARI ${ }^{1}$, YULI MULYAWATI ${ }^{2}$, TUSTIYANA WINDIYANI ${ }^{3}$, EVA MUTIA ${ }^{4}$ \\ 1,2,3,4 Program Studi Pendidikan Guru Sekolah Dasar, FKIP, Universitas Pakuan, Indonesia. \\ Email:1 1fitri.siti.sundari@unpak.ac.id, 2yuli_mulyawati@unpak.ac.id, \\ 3tustiyana@unpak.ac.id, ${ }^{4}$ evamutiakm31@yahoo.com
}

Article Received: October 22, 2019, Published Article: May 01, 2020

DOI: https://doi.org/10.29313/ga:jpaud.v3i2.5265

\begin{abstract}
This is quantitative research with a correlational study method, with the research title Relationship of Fine Motor Ability as an independent variable and Continuous Writing Skills as a dependent variable. The purpose of this study is to determine the relationship between fine motor skills and the ability to write upright to be connected to the sub-themes of harmonious living at home. This study's subjects were classes IIA, IIB, IIE, and IIF Papandayan State Elementary School, Bogor Tengah District, Bogor City, Odd Semester of the 2019/2020 Academic Year totaling 104 with a sample of 51 respondents. This study's data were obtained using the Guttman scale questionnaire using definite choices such as yes or no for acceptable motor ability variables and writing test assessments for the variable continuous writing skills. The results showed a positive and significant relationship between fine motor skills and vertical straight writing skills. This is based on statistical analysis, which results in a correlation coefficient (rxy) of 0.714 and the pattern of the problem becomes $\hat{Y}=39.42+(0.476 \mathrm{x})$, which means the level of relationship is relatively healthy, and a tcount of 7.14 is greater than the table with a real level of significance 0.05 of 2,404 and the table with a real level of 0.01 of 1,676 which means significant. Based on the results of this study, it can be concluded that there is a strong, positive, and significant relationship between the relationship of fine motor skills with continuous writing skills
\end{abstract}

Keywords: Fine Motor; Writing Skills Upright.

\begin{abstract}
Abstrak
Penelitian ini merupakan penelitian kuantitatif dengan metode studi korelasional, dengan judul penelitian Hubungan Kemampuan Motorik Halus sebagai variabel bebas dan Keterampilan Menulis Tegak Bersambung sebagai variabel terikat. Tujuan penelitian ini adalah mengetahui hubungan kemampuan motorik halus dengan keterampilan menulis tegak bersambung pada sub tema hidup rukun di rumah. Subjek penelitian ini adalah kelas IIA, IIB, IIE, dan IIF Sekolah Dasar Negeri Papandayan Kecamatan Bogor Tengah Kota Bogor Semester Ganjil Tahun Pelajaran 2019/2020 berjumlah 104 dengan sampel sebanyak 51 responden. Data penelitian ini diperoleh dengan menggunakan kuisioner skala Guttman menggunakan pilihan yang pasti seperti ya atau tidak untuk variabel kemampuan motorik halus dan menggunakan penilaian tes menulis untuk variabel keterampilan menulis tegak bersambung. Hasil penelitian menunjukkan bahwa terdapat hubungan positif dan signifikan antara kemampuan motorik halus dengan keterampilan menulis tegak bersambung. Hal ini berdasarkan analisis statistik yang menghasilkan koefisien korelasi $\left(r_{x y}\right)$ sebesar 0,714 dan dalam pola permasalahannya menjadi $\hat{Y}=39,42+(0,476 x)$ yang berarti tingkat hubungan tergolong kuat dan diperoleh $t_{\text {hitung }}$ sebesar 7,14 lebih besar dari $t_{\text {tabel }}$ dengan taraf nyata nyata 0,05 sebesar 2,404 dan tabel dengan taraf nyata 0,01 sebesar 1,676 yang berarti signifikan. Berdasarkan hasil penelitian tersebut, dapat disimpulkan bahwa terdapat hubungan yang kuat, positif dan signifikan antara hubungan kemampuan motorik halus dengan keterampilan menulis tegak bersambung.
\end{abstract}

Kata Kunci: Motorik Halus; Menulis Tegak Bersambung. 
Golden Age: Jurnal Pendidikan Anak Usia Dini, Volume 3 Nomor 2 (Desember 2019)

ISSN 2549-8371 | E-ISSN 2580-5843

Fitri Siti Sundari, Yuli Mulyawati, Tustiyana Windiyani, Eva Mutia / Relationship Of Fine Motor

Skills With Vertical Writing Skills at Papandayan Public Elementary School Bogor

\section{INTRODUCTION}

Skills are activities that must be mastered by all people. In education, learning skills have their criteria and assessments because skills are the main provisions of students in the learning process. The skills that the participants learned were very many, one of which was the continuous writing skill. The skill of writing upright is the primary skill that must be mastered by students. Through continuous writing skills is a series of several letters into words, a series of several words into a sentence that contains its meaning and meaning, with the aim that students can learn to communicate through writing.

The results of the 2015 Program for International Student Assessment (PISA) report related to the competencies of children in Indonesia. The program that ranks the quality of the education system in 72 countries shows that Indonesia is ranked 62. "Our competence lags far behind other countries in the world," said children's education expert from Wahana Visi Indonesia. Also seen in schools' learning activities, there are still many once students are lazy to write, so the writing they produce is not in line with expectations. In the process of writing, students seem rushed to get it done quickly so many letters are left behind, it is unclear what form of letters they write, there are even writing written students are not shaded or not real, the fine motor skills of students must be trained to achieve success,

According to the observations and observations conducted in the class IIA, IIB, IIE, and IIF homeroom classes, many similar problems occur in the class, especially in fine motor skills with writing uprightly connecting students during learning activities at school. If present, the continuous writing skill from class $2 \mathrm{~A}$ is around $35 \%$, class $2 \mathrm{~B}$ is about $30 \%$, class $2 \mathrm{E}$ around $40 \%$ class $2 \mathrm{~F}$ around $30 \%$. It can be seen from the assessment of children's writing skills while doing writing activities at school.
Problems at school include not writing calmly so that the writing produced by many letters is lacking or left behind. The writing's intent is not visible or illegible. Even students do not place uppercase and lowercase letters correctly on their writing or writing the name or beginning of a sentence that should start with a capital letter, students write in small letters.

Based on the background of the problem above, the formulation of the problem in this study is; Is there a relationship between fine motor skills and continuous writing skills in class II Papandayan SDN Bogor City Odd Semester Academic Year 2019/2020?

The purpose of this study was to determine the relationship of motor skills with continuous writing skills in class IIA, IIB, IIE, and IIF Papandayan SDN Bogor City Odd Semester Academic Year 2019/2020.

\section{THEORETICAL REVIEW Interlocked Writing Skills}

Write skills erect concatenated has a variety of involvement in its activities, which involve a variety of activities that support the development of fine motor skills as trained sensory like touch the $h$ 's, then the complex activities that other cause various forms of visual or non-visual, following the opinion of the Widyastuti (2017: 155) according to him, writing continuous upright is a complex activity that involves the integration of sensory, visual, touch, and fine motor skills.

The skill of writing upright also has various criteria that can be assessed besides the opinion of Sholcan, the assessment can be started from the way students hold the writing. From the way the students move their hands, the neatness of writing, the completeness of the letters, when students copy the writing, and the way the participants the students write and deliver writing that has a specific meaning, it is about the indicators of writing skills according to Na'fiah (2018: 118), Efendi (2017: 285) and Hidayah 
(2016: 2,178) that the indicators of the beginning of writing include several assessment criteria including; 1) hold a pencil or stationery correctly; 2) hand movements and sitting position when writing; 3) tidiness in writing words or sentences; 4) clarity in writing letters; 5) Completeness of letters when writing; 6) Copy sentences correctly; 7) Write down words or sentences strictly following what the teacher dictates; 8) Posts can be read by others.

The skill of writing upright is a combination of several letters arranged into a word and then into a beautiful sentence, aimed at giving messages and information to the reader.

\section{Fine Motor Ability}

Motor skills consist of two parts, namely, fine motor and gross motor skills. Both are essential to support optimal student growth. However, for low classes, students' fine motor skills are essential because if they do not get good sufficient motor training, the possibility of participants students to achieve gross motor skills not by what is desiredunderstanding fine motor skills according to Rochma (2017: 3) that fine motor skills are skills in coordinating the movements of small muscles (hand and finger muscles) that are used to perform various activities that require eye and hand coordination.

Fine motor skills have indicators that must be achieved in their development by the use of fingers, wrist, and arm use; this is an initial step for students to start writing that can be assessed with three assessment criteria according to the achievement indicators being studied in school, by the opinion of Ningsih (2015: 3 ) that Indicators of fine motor skills 1) The use of fingers as needed, not all movements or role as opposition; 2) The use of the wrist as the primary function in regulating the direction, power or strength in carrying out activities can be gentle or full of strength; 3) The use of body parts marked by hands, arms, and fingers all moves under the command of the eye; 4) The indicator has category three assessments, starting from MB (starting to develop), BSH (Developing as Expected), and BSB (Developing Very Well).

There are so many factors that affect fine motor development, such as factors that are influenced by poetry that cannot be prevented, or can also be influenced by environmental factors that can be prevented, following according to Yusuf (2018: 31 -61) that there are two factors that influence development, the first genetic factors that are indirectly inherited because of the influence of the quality of the nervous system, the biochemical balance of the body, and the structure of the body, and the second is environmental factors that are restricted to family environments, peer school environments and mass media.

Difficulty in adapting can affect the motor skills of students; as revealed by Dahlan (2015: 73) motor disturbances can be seen when students are doing activities that involve one limb such as the hand, students cannot write correctly, and the results of writing are not can be read fluently, also, when students make movements that rely on the movements of the hands and feet, such as exercising, dancing, catching a ball or throwing a ball will not be accurate. Also, when walking, students crash into furniture, drop stationery and books, and show their awkwardness in associating with peers or with members of the opposite sex.

Sufficient motor ability is the movement of a small part of the body that does not require considerable energy. To hone students' fine motor skills, students must be given training and play so that students are not saturated. If not trained properly, this motor ability will be affected by various disorders caused by two factors, genetic (hereditary) or environmental factors.

\section{RESEARCH METHODOLOGY}

The study was conducted by the correlational method through the following research plan; 
Fitri Siti Sundari, Yuli Mulyawati, Tustiyana Windiyani, Eva Mutia / Relationship Of Fine Motor Skills With Vertical Writing Skills at Papandayan Public Elementary School Bogor

This research was conducted on students of class IIA, IIB, IIE, and IIF at SDN Papandayan located at Jalan Papandayan No.25 RT 1 RW 3 Babakan Village, Bogor Tengah District, Bogor City.

This correlation study was conducted in the odd semester of the 2019/2020 school year. The determination of the study refers to the school's academic calendar.

This study population consisted of IIA, IIB, IIE, and IIF in SDN Papandayan, Central Bogor District, Bogor City in Odd Semester Academic Year 2019/2020, amounting to 104 students. The sample used in the study were 51 students from Class II.

The research aims to determine the relationship between two variables: the variable sufficient motor ability as an independent variable $(x)$ while the continuous writing skills are dependent (y). the constellation of research variable problems as follows;

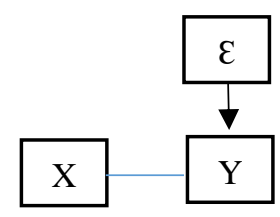

Figure 1. Constellation of Research Problems

Data collection techniques in this study used a questionnaire in the form of a questionnaire (statement) using the Guttman Scale with alternative answers consisting of two definite choices namely, yes or no, for acceptable motor ability variables, whereas for variable upright writing skills using continuous writing tests tested by expert judgment.

Variable sufficient motor ability using a questionnaire of 40 items. The instrument test was conducted on 30 respondents. The validity of the nontest instrument trials using the Pearson Product moment formula, the reliability test of the research instrument using Cronbach Alpha calculations, before the statistical hypothesis test is performed, the research data must first meet the prerequisites of the analysis by using the estimated error normality test and linear regression test.

\section{RESEARCH RESULT}

The research data description is grouped into two parts: the data-dependent variable $(y)$ continuous writing skills and independent variables, $(x)$ fine motor skills. Description of each data with the highest score, lowest score, range of scores, mean (mean), values that often appear (median), values that often appear (mode), standard deviation (SD), variance sample, and total score. The data is described in the form of statistical description and can be seen in the table below;

Table 1. Statistical Data on Research Results

\begin{tabular}{lcc}
\hline Element of Statistics & Variable X & Y variable \\
\hline Highest Scores & 100 & 100 \\
\hline Lowest score & 43 & 56 \\
Range of Scores & 57 & 44 \\
Average (mean) & 86 & 80 \\
Median & 91 & 83 \\
Mode & 93 & 87 \\
Variance & 16 & 118 \\
Standard Deviation & 266 & 11 \\
Total Score & 4383 & 4097 \\
Distance Class & 8 & 6 \\
\hline Many Class Intervals & 7 & 7 \\
\hline
\end{tabular}

Table 2. Frequency Distribution of Fine Motor Capabilities ( $\mathrm{x}$ )

\begin{tabular}{|c|c|c|c|c|}
\hline $\begin{array}{l}\text { Value } \\
\text { Interval }\end{array}$ & $\begin{array}{l}\text { Class } \\
\text { limit }\end{array}$ & $\begin{array}{c}\text { Middle } \\
\text { value }\end{array}$ & Fabsolut & $\begin{array}{c}\text { Relative } \\
(\%)\end{array}$ \\
\hline $\begin{array}{l}43-50 \\
\end{array}$ & $\begin{array}{c}42.5- \\
50.5\end{array}$ & 46.5 & 3 & 5.9 \\
\hline $51-58$ & $\begin{array}{c}50.5- \\
58.5\end{array}$ & 54.5 & 3 & 5.9 \\
\hline $59-66$ & $\begin{array}{c}58.5- \\
66.5\end{array}$ & 62.5 & 2 & 3,9 \\
\hline $67-74$ & $\begin{array}{c}66.6- \\
74.5\end{array}$ & 70.5 & 4 & 7.8 \\
\hline 75-82 & $\begin{array}{c}74.5- \\
82.5\end{array}$ & 78.5 & 1 & 2 \\
\hline
\end{tabular}


Golden Age: Jurnal Pendidikan Anak Usia Dini, Volume 3 Nomor 2 (Desember 2019)

ISSN 2549-8371 | E-ISSN 2580-5843

Fitri Siti Sundari, Yuli Mulyawati, Tustiyana Windiyani, Eva Mutia / Relationship Of Fine Motor Skills With Vertical Writing Skills at Papandayan Public Elementary School Bogor

\begin{tabular}{ccccc}
\hline $83-90$ & $82.5-$ & 86.5 & 9 & 17.6 \\
& 90.5 & & & \\
\multirow{2}{91-98}{} & $90.5-$ & 94.5 & 29 & 56.9 \\
& 98.5 & & & \\
& amount & & 51 & $100 \%$ \\
\hline
\end{tabular}

Based on the above frequencies, the highest score of 100 can be obtained, while the lowest score is 43 , with a range of scores of 57 , the total score (total score) of 4383 , many classes of 7 , class intervals of 8 , average scores of 86 , and scores variance 266 and standard deviation of 16 .

The results of the frequency distribution can be seen in the histogram diagram below.

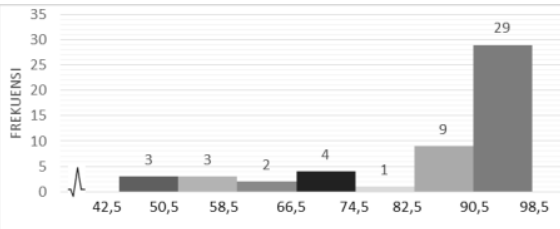

Figure 2. Distribution Histogram Diagram Data from the results of Fine Motor Ability Research $(X)$

Based on the histogram diagram above, it can be seen that the highest number of frequencies is about 90.5 - 98.5 with 29 students (56.9\%) and the lowest frequency with a range of $74.5-82.5$ with one student ( $2 \%)$

Table 3. Frequency Distribution of Continuous

\begin{tabular}{ccccc}
\multicolumn{5}{c}{ Writing Skills Data $(Y)$} \\
\hline $\begin{array}{c}\text { Value } \\
\text { Interval }\end{array}$ & $\begin{array}{c}\text { Class } \\
\text { limit }\end{array}$ & $\begin{array}{c}\text { Middle } \\
\text { value }\end{array}$ & Fabsolut & $\begin{array}{c}\text { Relative } \\
(\%)\end{array}$ \\
\hline $\mathbf{5 6 - 6 1}$ & $55.5-$ & 58.5 & 2 & 3,9 \\
& 61.5 & & & \\
$\mathbf{6 2 - 6 7}$ & $61.5-$ & 64.5 & 5 & 9.8 \\
& 67.5 & & & \\
$\mathbf{6 8 - 7 3}$ & $67.5-$ & 70.5 & 4 & 7.8 \\
& 73.5 & & & \\
$\mathbf{7 4 - 7 9}$ & $73.5-$ & 76.5 & 8 & 15.7 \\
& 79.5 & & & \\
$\mathbf{8 0 - 8 5}$ & $79.5-$ & 82.5 & 11 & 21.6 \\
& 85.5 & & & \\
$\mathbf{8 6 - 9 1}$ & $85.5-$ & 88.5 & 12 & 23.5 \\
& 91.5 & & & \\
\hline
\end{tabular}

\begin{tabular}{ccccc}
\hline $\mathbf{9 2 - 9 7}$ & $91.5-$ & 94.5 & 9 & 17.7 \\
& 97.5 & & & \\
& amount & & 51 & $100 \%$ \\
\hline
\end{tabular}

Based on the above frequency, the highest score is 100 and the lowest is 56 ; average value of 80 , a median value of 83 , a mode value of 87 , a sample variant of 118 , and a standard deviation of 11 .

The results of the frequency distribution can be found in the histogram diagram below:

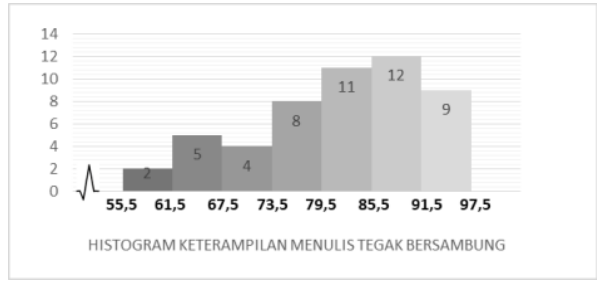

Figure 3. Data Distribution Histogram Diagram of Research Results of Continuous Vertical Writing Skills (Y)

Based on the histogram diagram above, it can be seen that the highest number of frequencies at $85.5-91.5$ is 12 students $(23 \%)$, and the lowest frequency in the range of $55.5-61.5$ is two students (3.9\%).

Table 4. Summary of Data Normality Test Variable Fine Motor Ability and Continuous Vertical Writing Skills

\begin{tabular}{|c|c|c|c|}
\hline $\begin{array}{l}\text { Estimated } \\
\text { Raw Error }\end{array}$ & $L_{\text {count }}$ & $L_{\text {table }}$ & Conclusion \\
\hline $\begin{array}{l}\text { Variables } \\
X \text { and } Y\end{array}$ & 0.0715 & 0.1241 & Normal \\
\hline
\end{tabular}

Based on the normality test using the Liliefors test, it was obtained that Lhitung $=0.0715$. The price is compared with the price of Ltable $=0.1241$ at the level of $a=0.05$, then the distribution of sufficient motor ability data $(X)$ with continuous writing skills $(Y)$ is declared normal. 
Golden Age: Jurnal Pendidikan Anak Usia Dini, Volume 3 Nomor 2 (Desember 2019)

ISSN 2549-8371 | E-ISSN 2580-5843

Fitri Siti Sundari, Yuli Mulyawati, Tustiyana Windiyani, Eva Mutia / Relationship Of Fine Motor Skills With Vertical Writing Skills at Papandayan Public Elementary School Bogor

Table 5 Summary of Homogeneity Tests

\begin{tabular}{cccc}
\hline $\begin{array}{c}\text { Variants } \\
\text { tested }\end{array}$ & $\mathbf{F}_{\text {count }}$ & $\mathbf{F}_{\text {table }}$ & Conclusion \\
\hline $\begin{array}{c}\text { Y over } \\
\mathbf{X}\end{array}$ & 1,499 & 4.04 & Homogeneous \\
$\mathbf{X}$ & & & \\
\hline
\end{tabular}

Significant Level Test Fcount $<\mathrm{F}_{\text {table }}$

Based on the homogeneity test results, the results of the skills to write upright and fine motor skills obtained Fcount of 1.499 for the number of samples 51 and significance level $\alpha=0.05$ obtained ftabel 4.04. the provisions applicable in the homogeneity test include:

$\mathrm{F}_{\text {arthmenic }}<\mathrm{F}_{\text {adule }}$ means homogeneous

$F_{\text {artimenic }}>F_{\text {tabe }}$ means not homogeneous

Because the $F_{\text {atitheic }}<f_{\text {tabe }}$ means the data used are homogeneous.

To explain the relationship between the variables of fine motor skills and vertical writing skills based on the results of the calculation of the significance test and expressed in the form of regression that is $=a+b(x)$ can be seen in the following transience diagram:

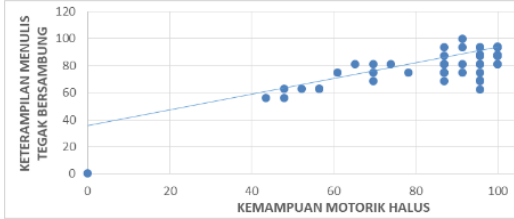

Figure 4. Transmission Diagram Relationship of Fine Motor Ability $(\mathrm{X})$ with Continuous Writing Skills $(\mathrm{Y})$

Based on the calculation results, the regression equation in the diagram shows that there is a correlation that there is a positive relationship and shows the closeness between the two variables with the provisions of the positive correlation of variable $Y$ will increase if variable $X$ rises, if variable $X$ is recognized, then variable $Y$ will also be controlled. The regression results above are used to test hypotheses about the presence or absence of a positive relationship between fine motor skills with vertical writing skills. The functional relationship between fine motor skills $(X)$ with continuous writing skills $(Y)$ significance test and expressed in the form of a regression equation is $\hat{Y}=a+b x$. After going through the relationship to find $a$ and $b$, the regression will change to $\hat{Y}=39.42+(0.476 \mathrm{x})$ where $X$ is the significance.

Hypothesis testing "there is a positive relationship between the variables of fine motor ability with the ability to write upright continuous" using the test of the significance of the path coefficient with the t-test. The test criteria for the significance of the path coefficient with the correlation coefficient is at the fundamental level of $5 \%$ or 0.05 if $t_{\text {arithmeic }}>t_{\text {abee, }}$, then the correlation coefficient is declared significant. The calculation of the significance test is outlined in the following table:

Table 6. Results of Significant Test Calculation of Correlation Coefficients

\begin{tabular}{|c|c|c|c|c|c|c|}
\hline \multirow[t]{3}{*}{$\mathbf{N}$} & \multirow{3}{*}{$\begin{array}{c}\text { Correlati } \\
\text { on } \\
\text { Coefficie } \\
\text { nt }\end{array}$} & \multirow{3}{*}{$\begin{array}{l}\mathrm{D} \\
\mathrm{K}\end{array}$} & \multicolumn{3}{|c|}{ Significance } & \multirow{3}{*}{$\begin{array}{c}\text { Conclusi } \\
\text { on }\end{array}$} \\
\hline & & & \multirow{2}{*}{${ }_{\text {count }}^{t}$} & \multicolumn{2}{|c|}{$\mathrm{t}_{\text {table }}$} & \\
\hline & & & & 0.05 & 0.01 & \\
\hline 5 & 0.71 & 0. & 7.1 & 2,40 & 2,70 & significant \\
\hline 1 & & 5 & 4 & 6 & 4 & \\
\hline
\end{tabular}

Based on the significance test calculation results obtained $t_{\text {count }}=7.14$ with ttabel $(\alpha=0.05)=$ 2.034 with a degree of validity (dk) 0.5 , the obtained $t$ tabe at a significant level is 2.034 so that $\mathrm{H}_{\text {o }}$ is in the interval -2.034 until 2,034. If $\mathrm{H} 0$ is accepted if the value of $t$ is calculated at -2.034 to 2.034 . $\mathrm{HO}$ is rejected if the calculated value $\leq 7.14$.

The research data can be described in the following curve: 
Fitri Siti Sundari, Yuli Mulyawati, Tustiyana Windiyani, Eva Mutia / Relationship Of Fine Motor Skills With Vertical Writing Skills at Papandayan Public Elementary School Bogor

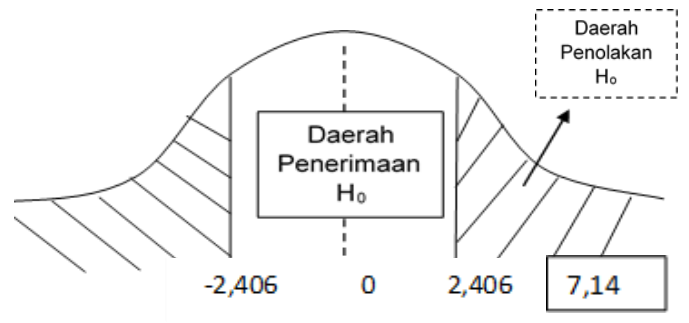

Figure 5. Rejection and Acceptance Curves $\mathrm{H}_{0}$

\section{DISCUSSION}

Based on the results of the analysis of hypotheses testing data, it is known that there is a positive and insignificant influence of fine motor skills with continuous writing skills. In other words, the research hypothesis is accepted.

The relationship between fine motor skills and statistically continuous writing statistically was shown with the results of the significance and regression tests with the regression equation $\hat{Y}=$ $39.42+0.476 x$. This means that every increase of one unit of variable fine motor ability will increase the continuous vertical writing skills of 0.476 units.

The relationship between fine motor skills and vertical writing skills is indicated by a correlation coefficient of 0.714 . The correlation coefficient price shows that there is a strong relationship between the variables of fine motor skills with the ability to write upright. In addition, from the results of the calculation of the significance of the path coefficient obtained data thus tcount $>t$ table $(a=0.05)>t$ table $(a=0.01)$ $=07.14<2.406<2.704$. This shows that there is a significant positive relationship given by fine motor skills to the skill of writing upright.

Based on the contribution of fine motor skills with vertical writing skills indicated by the coefficient of $50.98 \%$ determination. This indicates an increase or decrease in the ability to write upright is influenced by fine motor skills by $50.98 \%$, while other factors influence the remaining 49.02\%.

According to Damayanti (2011: 176), welltrained fine motor children will make it easier for children in writing activities closely related to fine motor skills. But fine motor skills too, are not the only factors that play an important role in improving children's writing skills.

The results of the above research data are supported by Nafi'ah (2018: 107), Erlina (2015: 6), and Sholchan (2014: 6.10), which confirms that writing upright or smooth writing is common in a low class, with practice and various techniques such as writing with high and low differences in writing, bowing and not bowing, tailing and not tailing, so that students are accustomed to writing neatly, well and discipline so that others can read it.

The results of this study are consistent with the results of a study conducted by Damayanti in 2011 entitled "the relationship between batik skills and fine motor skills with the ability to write children 6-8 Years at the Tunas Muda Private Primary School of the TNI Family Welfare Association Pragati Wira Anggini Palmerah West Jakarta". The study results stated that there was a negative relationship between the fine motor $(\mathrm{X} 2)$ with writing ability $(\mathrm{Y})$ with a correlation coefficient ry $1=0.862$. That means better fine motor skills will improve children's writing abilities. Conversely, if fine motor skills are low, then the child's writing ability will also below.

Based on Research Results from Maulfi Hakim Arridho. Thesis. Surakarta: Faculty of Teacher Training and Education, Sebelas Maret University, January 2010. This study was conducted to determine the relationship between physical fitness levels and motor skills in fifth-grade students at Mojosongo II State Elementary School Surakarta in $2010 / 2011$. This study's subjects were the fifth-grade students of SD Negeri II Mojosongo Surakarta, totaling 39 students. Data collection techniques with tests and physical fitness measurements were measured by TKJI consisting of: hanging body, bending elbows, lying in bed, jumping upright, running 40 meters for men, running 30 meters for girls, and running 600 meters. Moreover, the motor ability test with the Barrow motor ability test consists of a long 
Golden Age: Jurnal Pendidikan Anak Usia Dini, Volume 3 Nomor 2 (Desember 2019)

ISSN 2549-8371 | E-ISSN 2580-5843

Fitri Siti Sundari, Yuli Mulyawati, Tustiyana Windiyani, Eva Mutia / Relationship Of Fine Motor Skills With Vertical

Writing Skills at Papandayan Public Elementary School Bogor

jump without the start, running Zig-Zag, Medicine Ball Throwing Test. The data analysis technique used is simple linear correlation analysis and regression with a significance level of $5 \%$. Based on the results of the study, it can be concluded as follows: there is a significant relationship between the level of physical fitness with motor skills of Elementary School Age Students in grade V students at Mojosongo II Elementary School Surakarta in the academic year 2010/2011, with $r$ count $=0.5023588>r$ table $5 \%=$ 0.316 . Thus it can be concluded that there is a significant relationship between the two. The magnitude of the contribution of variable $X$ to $Y$ (determinant coefficient) of $25.2364 \%$ means the level of physical fitness contributes $25.2364 \%$ of motor ability.

From some of these opinions, it can be concluded that high students' fine motor skills can affect the ability to write upright students.

\section{CONCLUSION}

Based on data collection, data processing, and discussion of research results, it can be concluded that there is a relationship between fine motor skills and continuous writing skills in the subharmony of living at home in class II at SDN Papandayan, Central Bogor District, Bogor City, Bogor Semester 2019/2020

\section{REFERENCES}

Dahlan, Djawad M. (2015). Psychology of Child \& Youth Development. Bandung: PT Youth Rosdakarya.

Komaidi, Didik. (2017). Complete Guide to Creative Writing, Process, Skills, and Profession. Yogyakarta: Aksara Publisher.

Nafi'ah, Siti Anisatun. (2018). Indonesian Language Learning Models in Elementary / Ml. Yogyakarta: Ar-Ruzz Media.
Yuriastien, Effiana. (2009). Games Therapy for Baby and Child Intelligence. Jakarta: PT Wahyumedia.

Yusuf. (2018). Student Development. Jakarta: Rajawali Pres

Widyastuti, Ana. (2017). Tips on telling children who love reading and writing. Jakarta: PT Elex Media Komputindo.

Arridlo, MH (2010). Relationship between Physical Fitness and Motor Ability in Class V Students of Mojosongo II State Elementary School Surakarta in Academic Year 2010/2011 (Doctoral dissertation, Sebelas Maret University). Available at https://eprints.uns.ac.id/8682/ [Accessed on March 22, 2019]

Damayanti, Anita. (2011). The Relationship Between Batik and Fine Motoric Skills with Children's Writing Capabilities 6-8 Years [Thesis]. Jakarta (ID): Jakarta State University. Available at: http://en.portalgaruda.org/?ref= browse \& mod $=$ viewarticle $\&$ article $=$ 201153 [Accessed February 22, 2019]

Efendi, Rinja. (2017). Application of the Silaba Method to Improve Beginning Writing Skills in Indonesian Subjects. Rokania Education Journal [Online] Vol. 2 (2). 11 pages. Available at: https://www.ejurnal.stkiprokania.ac.id/index.php/jpr/ article / view / 41 [Accessed February 22, 2019]

Hidayah, Wani. (2016). Improvement of Beginning Writing Skills Using Diary of Students of Class IA SDN Plebengan Sidomulyo Bantul in 2015/2016. Vol. 2,713, 8 pages. Journal of Primary School Teacher Education [Online] Issue 28 of the 5th. Available at: http://journal.student.uny.ac.id/ojs/index.php /pgsd/article/view/4853/0 [Accessed on February 22, 2019]

Ningsih, Andri Setia. (2015). Identification of the development of children's fine motor skills in various play activities in groups $\mathrm{b}$. Journal of Early Childhood Education [Online] 4th edition 7 years 124 Pages Available at 
Golden Age: Jurnal Pendidikan Anak Usia Dini, Volume 3 Nomor 2 (Desember 2019)

ISSN 2549-8371 | E-ISSN 2580-5843

Fitri Siti Sundari, Yuli Mulyawati, Tustiyana Windiyani, Eva Mutia / Relationship Of Fine Motor Skills With Vertical Writing Skills at Papandayan Public Elementary School Bogor

http://journal.student.uny.ac.id/ojs/index.php /pgpaud/ article/view File / 377/343. [Accessed on March 1, 2019]

Rochma. (2017). Improvement of Early Childhood Fine Motoric Development through Mosaic
Activities in Agam Trustees' Kindergartens. Journal of Education, Social, and Culture [Online], Vol 6 (36) 13 pages. Available at: http://ejournal.unp.ac.id/index.php/paud/artic le/viewFile / 1633/1407 [Accessed March 1, 2019] 